\title{
Geographies of Empty Spaces on Print and Digital Reference Maps: A Study of Washington State
}

Sterling Quinn

Central Washington University

sterling.quinn@cwu.edu

\begin{abstract}
J. B. Harley's insistence that "there is no such thing as an empty space on a map" invites critical inquiry into which places are being left blank in popular reference maps, and why. I discuss the myriad reasons that items may not appear on a map, and invite a rethinking of the way selection is conceptualized in cartographic education. In this study, several GISsupported methods are used to identify and compare consistently empty areas in print and digital maps of Washington State made by Google, Microsoft, OpenStreetMap, Rand McNally, National Geographic, and the state Department of Transportation. I then examine the physical and human landscapes of these places using imagery overlays, queries of land ownership data, and observations from site visits. In the state of Washington, empty spaces on the map are highly connected with regional and global economies, and are essential for supporting the needs of urban life such as food, electricity, construction, and waste disposal. City dwellers may not ever see or recognize the intensive land uses occurring in these geographies, whose landowners include an intriguing mix of large industries, multiple levels of government, religious colonies, and individuals searching for space and solitude.
\end{abstract}

KEYWORDS: cartographic selection; critical cartography; empty spaces; cartographies of silence; digital maps; Google Maps; Bing Maps; OpenStreetMap; Washington State

\section{INTRODUCTION}

Ask An InTRODUCTORY cartography class why something might not appear on a map, and you'll get a lively discussion. For example, the data might not exist, because it's not considered important enough to be worth the investment of collecting it. Or it may be impossible to collect, due to difficult terrain, weather, armed conflict, or legal restrictions. Perhaps the data does exist, but we simply don't know about it, or it is censored by a more powerful authority.

But even in situations where sensors repeatedly traverse the full landscape and data flows liberally, empty spaces can persist on the map. The complexity of landscapes forces cartographers to make difficult choices about which features to include and exclude. Carefully exercised selection decisions can lead to efficient, memorable, and easyto-read maps (Delano-Smith 2004; Krygier and Wood 2016). At the same time, the selection process, influenced by the limitations of the mapmaker's knowledge and their implicit or explicit cultural biases, inevitably leaves some areas of the map canvas devoid of any entities or labels. These blank spots constitute a terra incognita on the map: literally "lands unknown," about which nothing can be understood without resorting to some other source.

The critical cartographer J. B. Harley $(2001,71)$ cautioned that "there is no such thing as empty space on a map." Yet, every map, out of necessity, has some blank areas in between features. What Harley meant is that something is always happening on the ground in a space, and when that space is depicted as empty, a cartographer has either deliberately or unwittingly deemphasized features of the landscape. As examples, Harley pointed to the omission of indigenous geographies from European maps of colonial America (thereby inviting appropriation by new peoples), as well as the decision by the United States Geological Survey topographic mapmakers to prioritize terrain and mineral deposits over cultural features (Harley 1990). 
Regardless of its cartographic depiction, no space is truly empty. At various scales, all spaces can afford a sense of place to the humans who interact with them and know about them (Tuan 1979). The terra incognita, then, exists only in our own minds (Wright 1947). Reference maps sharpen our perceptions of place by communicating about the human and natural events and processes occurring on the ground. They help us ascribe meaning to what was unknown or perceived as empty. Theorists in critical cartography have sought to understand how the contents of maps enlarge and limit our possibilities to know about places and act on them (Crampton 2001). These inquiries should be broad enough to consider both what is shown and what is not shown.

Consequently, the purpose of this study is to first identify which spaces are being left empty in modern reference maps (in both print and web formats), and then to use ancillary sources to better understand the physical and human landscapes in these places. These supplemental resources include satellite imagery, street-level imagery, cadastral fabrics, and field visits. A goal is to see how empty map spaces and their associated landscapes produce each other through the ways people think about, talk about, and act upon these places. As Harley observed, "There's no neat causal arrow that flows from society into the map, but rather causal arrows that flow in both directions" (2001, 44).

\section{SELECTION}

An item appears on a map because somebody knew about it and decided to include it. Cartography textbooks often contain several paragraphs of guidance on the process of selecting what to map. For example, Kimerling et al. instruct that, "based on the map's purpose and scale the cartographer will choose the relevant information to include on the map and determine what should be left off" (2012, 207). According to Robinson et al., "selection is the intellectual process of deciding which classes of features will be necessary to serve the map's purpose" $(1995,405)$. Borden Dent $(1999,16)$ describes selection as working with the client to make early decisions about which data variables and other characteristics would be most appropriate for the map's purpose. Kenneth Field (2018, 294) situates cartographic selection as a process that occurs in tandem with generalization and symbolization after data has been collected.
Each of these authors depict the cartographer as a powerful agent selecting the most relevant facts from a realm of existing knowledge to fit into the available space, in the same way one would fill up a dinner plate while walking along a buffet table. But the situation is somewhat more complex than this, requiring more inquiry about what is on the table and why. For example, limitations in funding or equipment may narrow a mapmaker's choices of data, or the cartographer may not know about some entities that could be mapped. Selection might also be steered by business decisions, paid placement of points of interest, political intrigue, bribery, or censorship. Finally, a cartographer might exclude otherwise useful data out of a desire to protect vulnerable cultural and environmental resources or to respect the traditional lands of people who live in the mapped geography. Seldom do textbooks contain guidance about what not to map, although John Krygier and Denis Wood (2016, 36-37) advise caution when depicting secret or sensitive facilities and infrastructure, communally held lands, and phenomena that are impossible to capture in Cartesian space.

These cartography texts emphasize the connection between the act of selection and the purpose of the map. In this article I will be examining general reference maps of Washington State that could be used in multiple ways including education, navigation, trip planning, or (in the case of the web maps) overlaying more data. Maps designed for more nuanced purposes (such as mining, energy infrastructure management, wildlife management, etc.) might favor a much different set of features, although all would need some set of base features to provide geographic context. Those base features are the focus of this study.

\section{CARTOGRAPHIES OF SILENCE}

Harley (1988) devoted much of his attention to maps of European colonial activity, studying the ways that what he called "cartographic silences" reflected the power relationships between early modern European states and their citizens, colonized lands, and political rivals. These silences could be either unintentional or intentional. For example, indigenous place names and locations were often disregarded in colonial maps of the Americas either out of ignorance of the geography or a desire to show these lands as available for settlement. In early modern maps of Europe, symbols of religious authority were sometimes deemphasized due to rivalries between Catholics and Protestants. 
André Reyes Novaes (2014) argued that silences in modern maps also deserve scrutiny in order to understand how marginalized populations and places are represented. As evidence, he chronicled how Rio de Janeiro's official maps mostly ignored the city's informally settled favela neighborhoods until the 1990s. The controversy persisted with Google Maps, which incurred criticism for diminishing its representations of the favelas between 2011 and 2013. Stanley Brunn and Matthew Wilson (2013) lamented a similar dearth of digital geographical information about the majority-black township of Khayelitsha, in greater Cape Town, South Africa.

In these ways, empty spaces hide people and activities from public view, thereby perpetuating the process of marginalization. Kimerling et al. (2012, 488) describe how maps of combat targets in the Vietnam War omitted place names, using impersonal numerical codes that separated pilots from the places being bombed. Crowdsourced maps uniquely counter this type of silence by allowing people to place themselves on the map and emphasize aspects of their communities that may be omitted elsewhere. For example, residents of the largest informal settlement in Nairobi, Kenya, surveyed and placed their community into OpenStreetMap (Hagen 2011). The detailed map made it more difficult for the space to be ignored by local authorities. Elsewhere, plotting urban farms and gardens in OpenStreetMap has promoted the re-imagining of vacant lot spaces that often languish empty in digital maps (Quinn and Yapa 2016).

Yet, there are still many reasons why remaining off the map might be viewed as advantageous, especially by those who want to maintain their privacy or conduct activities outside the gaze of the camera (Novaes 2014). For example, in his inquiry into unmapped "black ops" sites used for interrogation by US intelligence personnel, Trevor Paglen (2009, 276-277) proposed that blank spots on the map have helped create blank spots in the law. What is not known can neither be regulated nor policed.

Nor can it be attacked. For this reason, British Ordnance Survey maps once omitted sensitive military and intelligence installations, depicting them instead as farms or vaguely-titled entities such as "depot" (Perkins and Dodge 2009). The ubiquity of satellite imagery eventually put an end to this deception, but debates about how to depict such facilities rage on. For instance, contributors to
OpenStreetMap in Israel have engaged in edit wars over whether to digitize military-related facilities or leave them off the map. ${ }^{1}$

Some efforts to keep the map empty are motivated by the desire to protect cultural or environmental resources, as well as communities and individuals. Because place names attract attention and visitors, the United States Board of Geographic Names maintains a policy of rejecting new toponym proposals within federal wilderness areas (Julyan 2000). Among outdoor recreationists, the locations of caves, archaeological sites, and even favorite fishing holes are often viewed as sensitive information, not to be shared in public media. Multitudinous indigenous groups and religious communities have preferred for their surroundings to remain unknown, untraversed, or unmapped by others, often to protect their ways of life. Fearing state incursion and the privatization of communal lands, indigenous communities in Oaxaca, Mexico expelled a team of academic mappers after learning that the research was funded by the United States military (Bryan and Wood 2015, 142-161).

How are GIS and algorithmically produced web maps producing cartographies of silence? Craig Dalton and Jim Thatcher (2019) examined how the business missions of large companies such as Google and Apple influence the points of interest displayed on their map products, as well as the ways that users interact with maps online. They noted that Google Maps began including advertisements for large chain businesses on its maps and driving directions. Users often want to search for these landmarks and navigate based on them; and yet, the deemphasis on local shops and cultural features has a cumulative effect on users' geographic knowledges, spatial behaviors, and imprints on the landscape.

Digital maps are typically composed of multiple data layers, each representing a certain class of entity on the landscape. For example, a map might be composed of a water layer, a shaded relief layer and a cities layer. However, any cultural or landscape feature that does not appear in the selected layers must be added manually by the cartographer, a costly endeavor for web maps that are automatically generated to cover many countries at many scales, often down to the neighborhood level. Harley (1988) foresaw this when he predicted that the "technologizing of the map" would lead to a narrowing of types of things being mapped, thereby creating "silences of the unique." 
It was perhaps for its ability to overcome these silences that Dave Imus's print map The Essential Geography of the United States of America drew so much critical acclaim (Stevenson 2012). The map contained the elements commonly expected in a wall map, such as state boundaries, shaded relief, and city locations; however, it also included influential cultural and environmental sites that fell outside the set of widely available GIS data layers. Examples include the locations of the Deepwater Horizon oil spill, World War II-era Japanese internment camps, and the Burning Man festival.

Imus was able to add these touches manually, but they required a degree of knowledge about the local cultural landscape that no algorithm can easily grasp. In automated cartography, features not deemed regular or repetitive enough to merit their own datasets or categories are in danger of being left off, thereby limiting an understanding of the complexity of the landscape (Wilmott 2019). Even though the crowdsourced nature of OpenStreetMap provides an avenue for myriad local knowledges to be added into a public geographic database, the map on OpenStreetMap.org is still limited by the demographics of the contributors and the set of feature types and tags agreed upon for the default tile renderer. For example, only recently were native reservations added to that map, an endeavor which took years of discussion (McConchie 2019; Wilmott 2019).

\section{LANDSCAPES OF EMPTY MAP SPACES}

Once the map's empty spaces have been demarcated, what approaches can we take to better understand these landscapes? Certainly, elements of physical topography should be identified; yet it is the human transformation of spaces that constitutes the most important morphologic factor in the study of landscapes and thereby influences most of the features in reference maps (Sauer 1925). People constantly use the landscape and alter it to meet their ends, sometimes in destructive ways. Even a seemingly barren or empty landscape in the "middle of nowhere" has likely been influenced by humans over time through processes of appropriation and transformation. Cultural meanings of the landscape, and the processes that shaped them, can be decoded through field visits, mapmaking, studies of historical maps, and scrutiny of promotional tourism literature (Lewis 1979; Cosgrove 1989). This process “allows us to reflect upon our own roles in reproducing the culture and human geography of our daily world" (Cosgrove 1989, 131).

In this tradition, Lester Klimm (1954) undertook a study of the "empty areas" of the northeastern part of the United States, which he defined as spaces without human settlement, agricultural activity, industry, roads, or mineral extraction. Klimm's team identified these areas primarily using government-produced topographic maps and state highway planning maps, although some photomaps supplemented the efforts. They then drove over 47,000 kilometers to field check the results. In Klimm's study, the major influences leading to an "empty" landscape were physical isolation from major economic centers and distance from historical routes of circulation. Although some discussion was offered about the origins of these centers and routes, Klimm attributed the cultural layout of the landscape to the "ffrozen history' of decisions-once with some rational explanation but now incomprehensible-by people long since dead" (343).

More recent scholarship has argued that a landscape is never stuck in time, but is constantly being forged by competing social actors. Don Mitchell (2008) cautioned that inquisitiveness and field visits alone cannot fully replace archival research, ethnography, and a grasp of social theory when it comes to understanding the ways that landscapes constitute social compromises and mediations. Observers of the landscape should also be attuned to the influences of capital and how spaces are used to generate revenues. These considerations are just as true in rural areas as they are in cities, as Mitchell demonstrated in his studies of the landscapes of agricultural labor in California (1994). Interestingly, Klimm designated areas of commercial forestry as empty and "passed over," yet as will be shown later in this paper, such areas are active sites of economic activity that influence major urban areas both near and far.

\section{METHODS}

To IDENTIFY AND STUDY the kinds of areas being omitted from popular reference maps, this study examines maps of Washington State (not to be confused with
Washington, DC), located in the northwest corner of the contiguous United States of America with a land area of 66,455 square kilometers and a population of over 6.7 
million people. The variety of landscapes in this region of the US makes Washington an ideal area to study. The state is sharply divided physiographically and culturally by the Cascade Range, which runs north-south through the entire length of the state. Most residents live in the western side of the state along Puget Sound and the Interstate 5 highway. This area is heavily forested with a maritime climate. The eastern inland side of the state is generally much dryer and more sparsely populated.

Six maps of Washington State were chosen for this study: three web maps and three designed for print. All of them are used by the public for navigation, tourism, and general geographic context and education. The three web maps were Google Maps, Bing Maps, and OpenStreetMap (with the default styling from OpenStreetMap.org). Several lab assistants and I captured and mosaicked screenshots of the entire state from the browser version of these maps in April 2019 at the approximately 1:1,156,000 scale. This scale is part of the traditional set of levels (zoom level 9) used for building multiscale tiled web maps.

The three print maps were:

- National Geographic Washington Guide Map, published in 2018 with a scale of 1:1,267,000.

- The two-page Washington spread from the Rand McNally 2019 Road Atlas, with a scale of approximately $1: 1,267,000$.

- The Washington State Highways 2014-2015 map, published by the Washington State Department of Transportation (WSDOT) at a scale of 1:842,000. This is the most recent year that WSDOT has published a print edition of its highway map.

We scanned the National Geographic and Rand McNally maps and obtained a digital version of the WSDOT map, identical to the print version, from WSDOT's website. We then georeferenced the maps by matching control points with features on the Esri Streets basemap; we typically used land boundary corners and road intersections as control points. Because of the scale of the maps and the resolution of the scans, there were, as expected, slight positional errors in the georeferenced maps; however, none of these was larger than the $5 \mathrm{~km}$ fishnet cell dimension used later in the study.

An early challenge in this study was deciding what should constitute "empty space." Take a look at any map and it soon becomes clear that the empty space isn't neat and compact: it's irregular and sinuous, winding around isolated features and labels spread out by cartographers who were trying to avoid placement conflicts. Should text disqualify a place from being empty? How about homogeneously tinted areas inside of large polygon boundaries, such as national forests or native reservations? Do background areas of shaded relief count? ${ }^{2}$

Because the topic of empty space is complicated in this way, two different approaches are detailed below: a manual method and an automated method. Using them together provides a picture of which areas are consistently left empty and deserve further study, although it doesn't arrive at a definitive boundary.

\section{MANUAL METHOD}

The first approach required the active participation of a human analyst to "manually" check over each map. To begin, all maps were projected into the Washington State Plane South coordinate system, and then overlaid with a grid of $5 \mathrm{~km}$ cells. ${ }^{3}$ We scrutinized each cell systematically and marked the ones that contained no map features. This process took about one to two hours for each map.

For this exercise, the intent was to identify "placeless" spaces, about which nothing would be known if the map were the only instrument; therefore, the only allowed markings in an "empty" cell were graticule lines, inset map extent boundaries, background shaded relief, and markers indicating distances between points on a road (although not the road itself). State and county labels and boundaries were also allowed, since all land is encompassed by these, and county labels are often used to fill empty space. The presence of other polygons and text disqualified a cell from being considered empty, since these items communicate something about the place. Ocean was excluded from both this analysis and the automated method described below.

2. The Bing, Google, and National Geographic maps contained shaded relief in the background, while the rest did not.

3. Statewide spatial datasets distributed by the Washington State government use the Washington State Plane South zone coordinate system. We chose this one in order to match their well-known practice. 


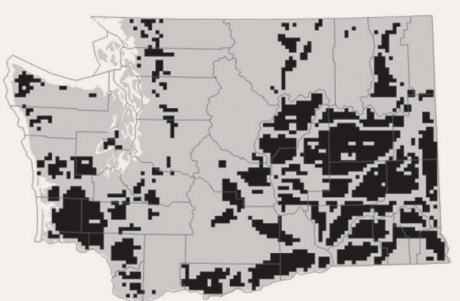

Bing Maps

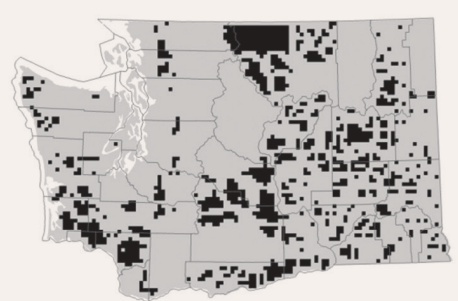

Google Maps

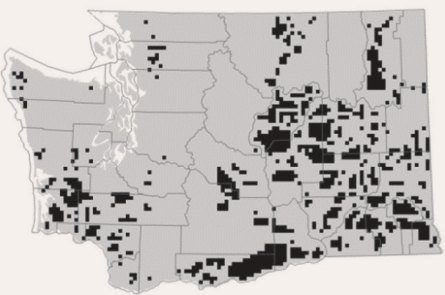

OpenStreetMap

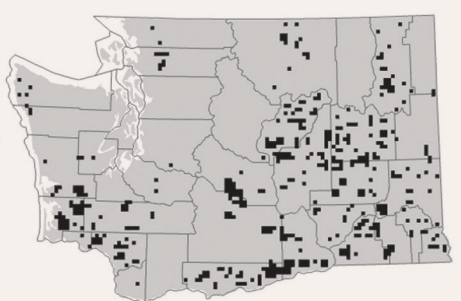

All three web maps

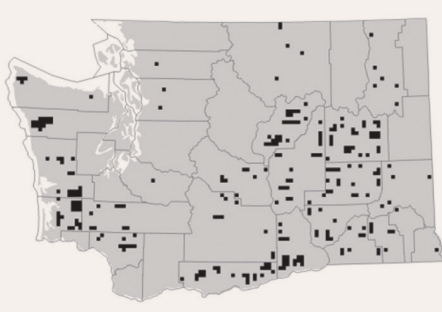

Rand McNally Atlas

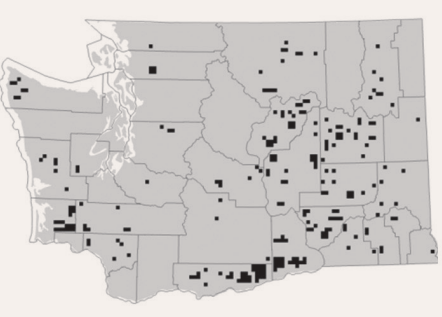

National Geographic Guide Map

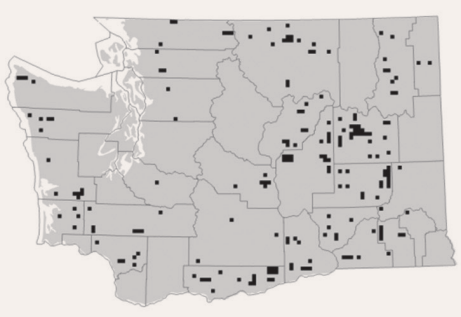

State Highway Map

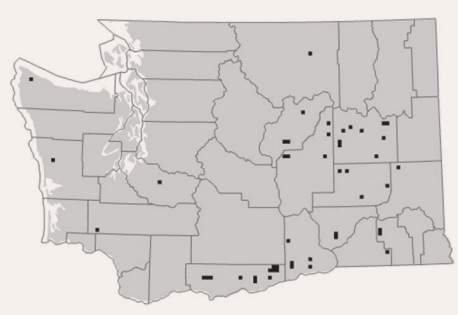

All three print maps

Figure 1. Empty spaces identified on each map using the manual method.

The process was repeated for all maps, with each receiving its own column in the grid's attribute table, marking whether that square was empty on that particular map. Figure 1 shows, in black, the empty cells for each individual map, as well as cells that were empty in all three maps of each type (web and print). The web maps had much more empty area than the print maps, likely because they were generated with the idea that the reader could zoom in to see more detail (it is unclear, however, how often map readers would zoom in to areas that were blank in the first place; this merits further study). The desire to avoid conflicts in automatic label placement might have also contributed to fewer features appearing in the web maps. In contrast, the print maps were limited to a single scale onto which the cartographers manually positioned as much information as possible. The WSDOT highway map has the least

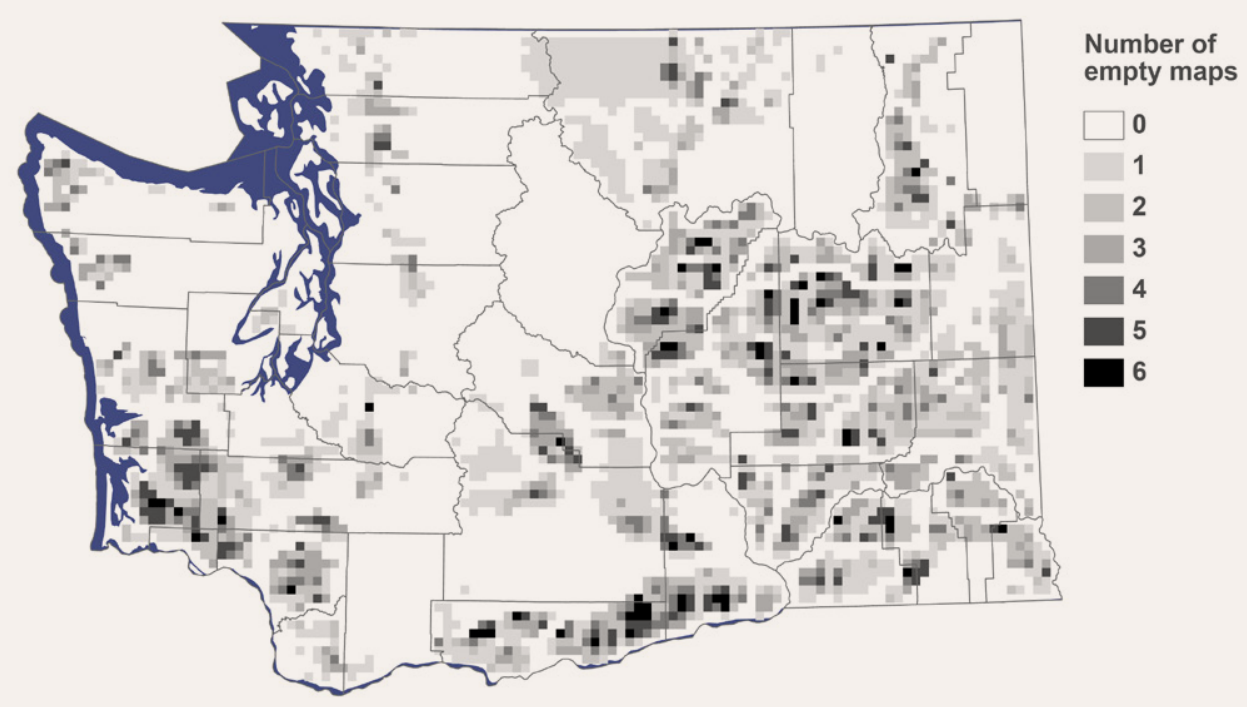

Figure 2. Composite result for the manual method showing number of maps marked as empty in each fishnet grid cell. 


\section{AUTOMATED METHOD USING} INTERPOLATION

Although the manual method described above reliably identifies the major empty spaces, it requires much time and attention from a human analyst and may be difficult to scale up to large map sets. It is also subject to the modifiable areal unit problem, meaning that different results could be obtained if the grid were shifted or the cell shape or size were changed.

We originally hoped that automated image processing methods could be used to determine the map background color and isolate homogeneous regions of that color; however, identifying these contiguous regions turned out to be complicated due to creases, shadows, bleed-through, and other artifacts in the scanned paper maps. The presence of background shaded relief likewise caused problems. To address these issues, it was necessary to generalize the patterns in the maps in order to identify regions that were more empty than other regions.

Since all the maps used a light background with darker features and labels on top, it followed that generally lighter areas of the image would be more devoid of features. In some kinds of mountain cartography, bold tones of shaded relief might interfere with this line of thinking; however, the shaded relief in the study maps was relatively light in color and nondescript.

To identify generally light and dark areas, we converted the maps to grayscale using the r.composite function in GRASS GIS (accessed via the QGIS processing toolbox). This resulted in each pixel having a single integer value indicating its amount of lightness. Next, the map patterns were generalized by extracting random pixel values and using these to interpolate a surface, effectively re-creating the map in blurred form. To carry this out, we buffered a Washington state boundary polygon by 5 kilometers to mitigate edge effects in the eventual interpolation. Then, 100,000 random points were generated within this polygon. To force a more spatially even distribution, points were required to be at least $0.5 \mathrm{~km}$ from any neighboring point. $^{4}$

For every map, a copy of the random points layer was made, each with an attribute table recording the grayscale

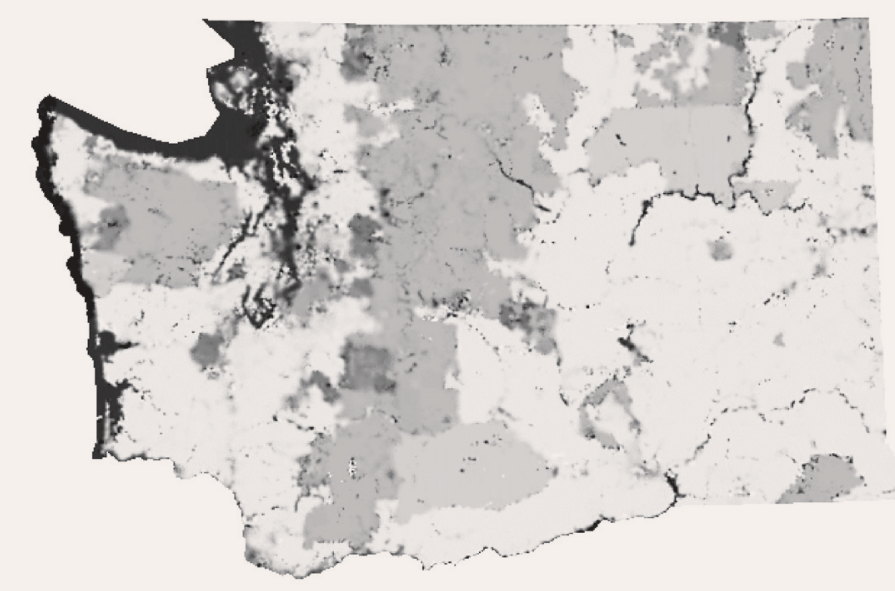

Figure 3. Interpolated surface for OpenStreetMap, showing generally light and dark areas.

pixel values intersecting each point. These points, now enriched with their underlying lightness values, were fed into the Empirical Bayesian Kriging tool in ArcGIS. Kriging is an interpolation method that uses trends in variance to generate custom weights for each neighboring point contributing to the interpolation (O'Sullivan and Unwin 2003, 265-281). Kriging was useful in this workflow because of the relatively smooth surfaces it generated; however, other kinds of interpolation methods could be used.

The kriging created a continuous interpolated surface that was then clipped to the Washington state boundary (with no buffer). The result was a smoothed or generalized version of the original map that made it easier to identify generally light and dark areas. The resolution of this surface was set at $1 \mathrm{~km}$, making its output more nuanced than the manual method. Figure 3 shows an example of one of these kriged surfaces (resulting from OpenStreetMap).

Next, the surfaces were reclassified to isolate the lightest pixels. Since all the maps had different distributions and ranges of grayscale values and some maps included shaded relief, it was not practical to apply a universal cutoff value separating light and dark. Instead, since higher pixel values indicated lighter areas on the map, any pixel falling more than half of one standard deviation above the mean pixel value in the map was reclassified as light and given a value of 1 , while all other pixels were reclassified 0 . Cutoffs higher than half a standard deviation tended to rapidly eliminate area to the point of not being useful.

4. Interpolation tests involving lattices of evenly-spaced points yielded comparable results to the random points. The evenly-spaced lattices were somewhat better at preserving shapes and linework in the interpolated surfaces, although the surfaces derived from random points detected some features that were missed in the gaps of the lattice. 


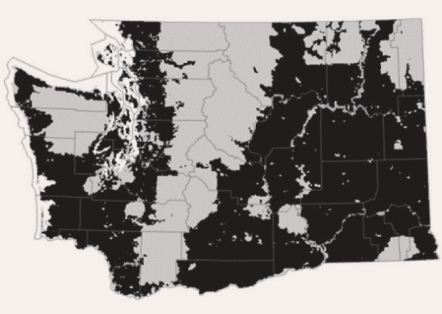

Bing Maps

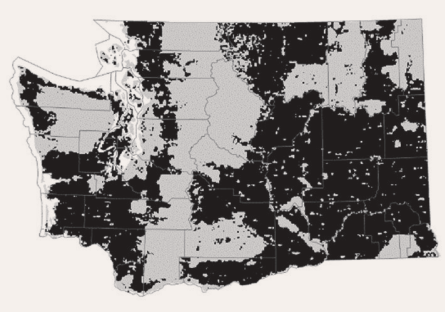

Google Maps

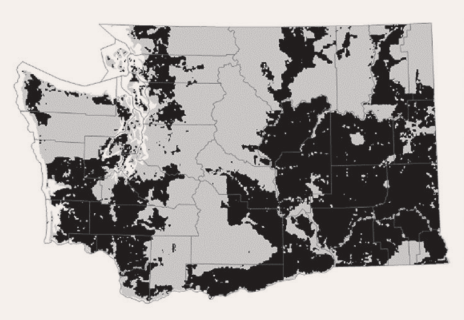

OpenStreetMap

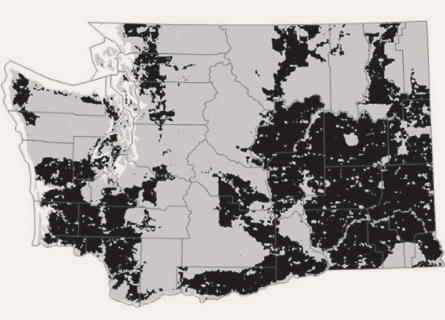

All three web maps

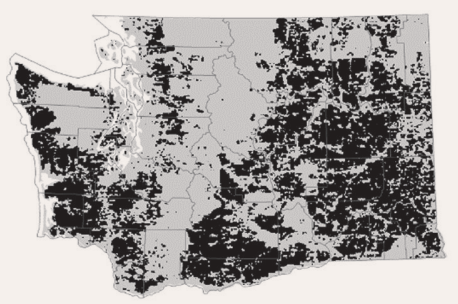

Rand McNally Atlas

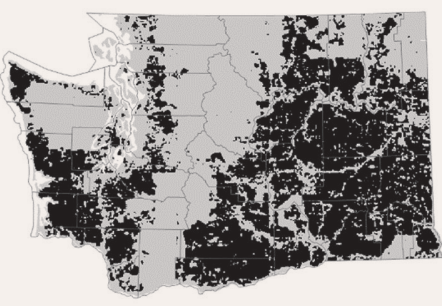

National Geographic Guide Map

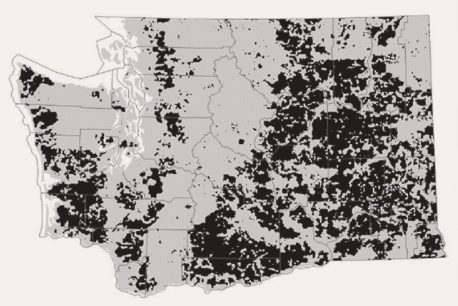

State Highway Map

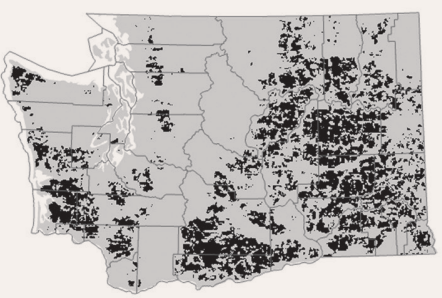

All three print maps

Figure 4. Empty spaces identified in each map using the automated method.

Figure 4 shows the six maps with "empty" areas above the cutoff symbolized in black. Again, the web maps show more empty area than the print maps.

The reclassified layers for the six maps were added together, indicating which areas tended to appear consistently empty (Figure 5). The $1 \mathrm{~km}$ cells of the automated method resulted in more nuanced spatial patterns than the $5 \mathrm{~km}$ cells of the manual method. Major highways like Interstate 90 and US 395 create discernible cuts through the empty spaces in eastern Washington. Differences in the inclusion of federal- and state-managed public lands are also apparent along the crisp vertical line dividing light and dark near the geographic center of the state (indicated by the red arrow in the figure). On the west side of the line, the Okanogan-Wenatchee National Forest is symbolized on most of these maps, while to the east, state-managed lands such as the L.T. Murray and Wenas wildlife areas are largely omitted.

\section{COMPARING AND COMBINING THE METHODS}

The automated method brings a potential for higher-resolution output, since using $1 \mathrm{~km}$ cells in the manual method

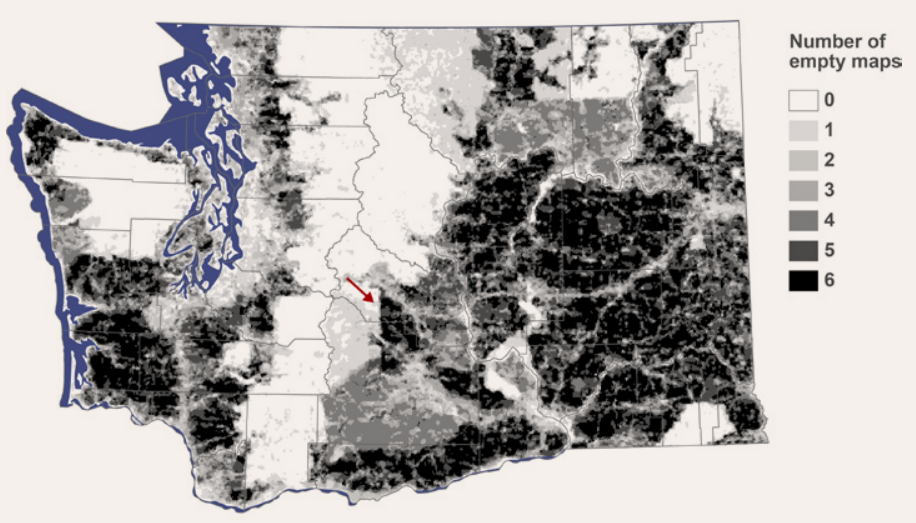

Figure 5. Composite result for the automated method showing number of maps that were empty for each raster cell. The arrow indicates a division between state- and federally-managed public lands.

would have been prohibitively time consuming. The lower resolution of the manual method also meant that very few cells were found to be empty in all six maps; to see more useful spatial patterns, it was better to also examine cells that were empty in four or five maps. The manual method, however, does result in greater certainty that the identified empty spaces are indeed empty on the map. 


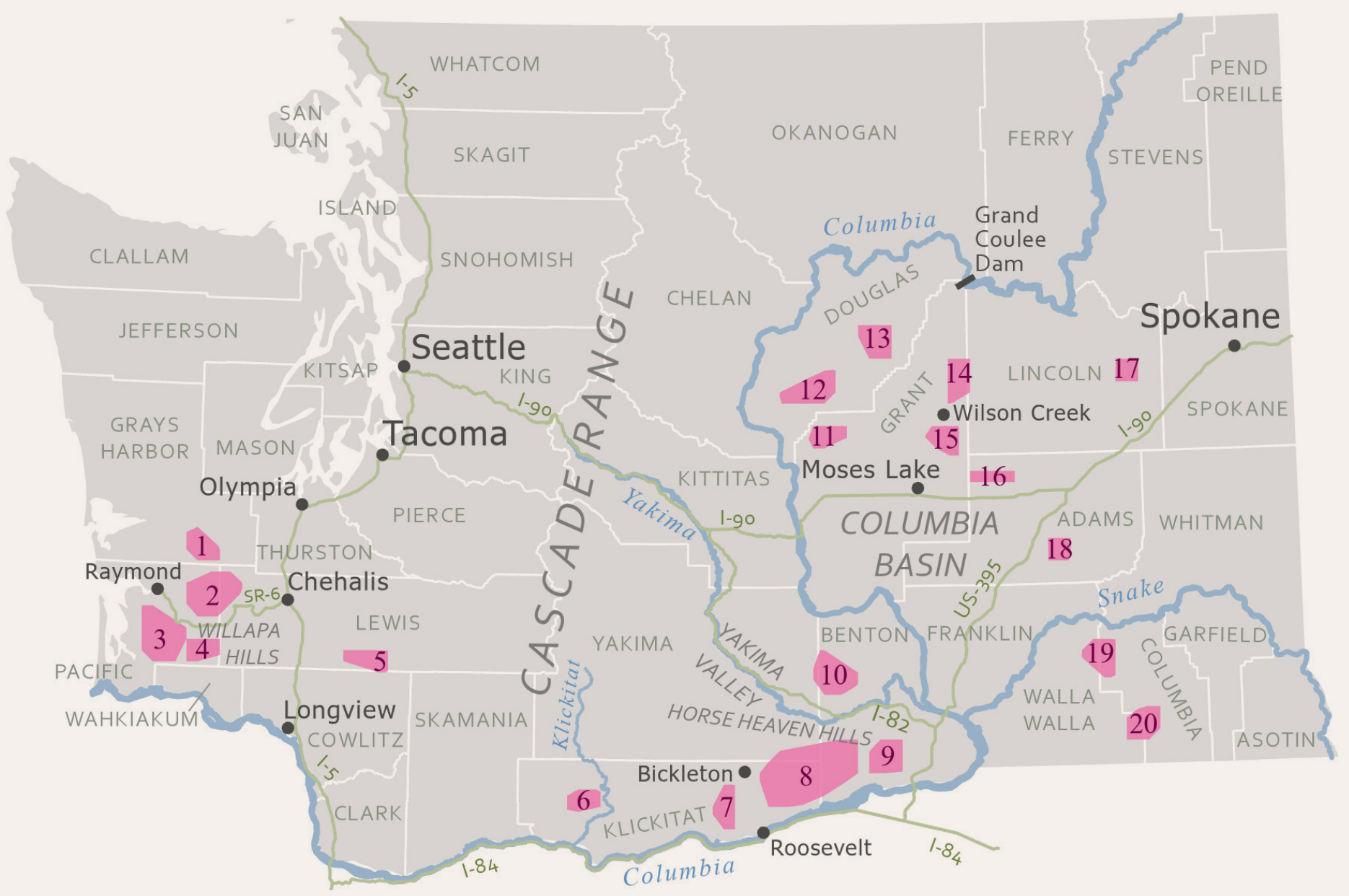

Figure 6. The most empty areas on the Washington State maps as identified by the methods in this study. Numbers are for referencing the areas, and do not indicate a quantitative metric.

With these things in mind, we combined the two methods by taking the areas found empty in all six maps when using the automated method, and then intersecting that with the areas found to be empty in four or more maps when using the manual method. The resulting polygons were very irregular in form, so convex hulls were drawn around the 20 largest to give them more comprehensible shapes. The polygons are shown in Figure 6, along with other geographical landmarks mentioned in this study.
Although there are scattered outliers, most of the polygons fall within three regions: (I) Willapa Hills timber country (areas 1-4), (II) high plains and plateaus between the Oregon border and the Yakima Valley (areas 6-9), and (III) dryland farms and shrub steppe on the periphery of the Columbia Basin Project (areas 11-18). The remaining outlying polygons (areas 5, 10, 19, and 20) each share characteristics with at least one of these three regions.

\section{EMPTY SPACES ON THE WASHINGTON STATE MAP}

IN ORDER TO BETTER UNDERSTAND the human and physical geography of these three regions, I overlaid additional GIS layers such as satellite imagery, tax parcels, and zoning. Street-level imagery such as that available on Google Street View was also examined where it was available, although many minor roads in the identified areas did not have any coverage. This information guided my visits to the three regions during September through November 2019. During these trips, I looked for signage about ownership and access, observed current land use practices, field checked information from the GIS layers, and toured industrial facilities. Following is a summary of the landscapes found in the three regions and how they connect with the regional, and even global, economies. 


\section{WILLAPA HILLS TIMBER COUNTRY}

Some of the largest contiguous regions of empty map area are in Southwestern Washington's Willapa Hills, mostly in Pacific County and the southern part of Grays Harbor County. The moderate temperatures, heavy rainfall, and old soils of this area all contribute to rapid tree growth. Nearly all of the "old growth" present at the arrival of white settlers has been felled, and nowadays the forests are planted, nourished, thinned, and then entirely cut down on a roughly 50-year cycle. A view of satellite imagery in the area (Figure 7) shows a patchwork of timber lands in all stages of growth, from clear cut to ready-to-harvest trees. Figure 8 gives a view of this landscape on the ground.

Empty map areas in the Willapa Hills are owned primarily by Weyerhaeuser (which holds over $20 \%$ of the land area of Pacific County) and the State of Washington (which relies on timber revenue as source for local budgets).

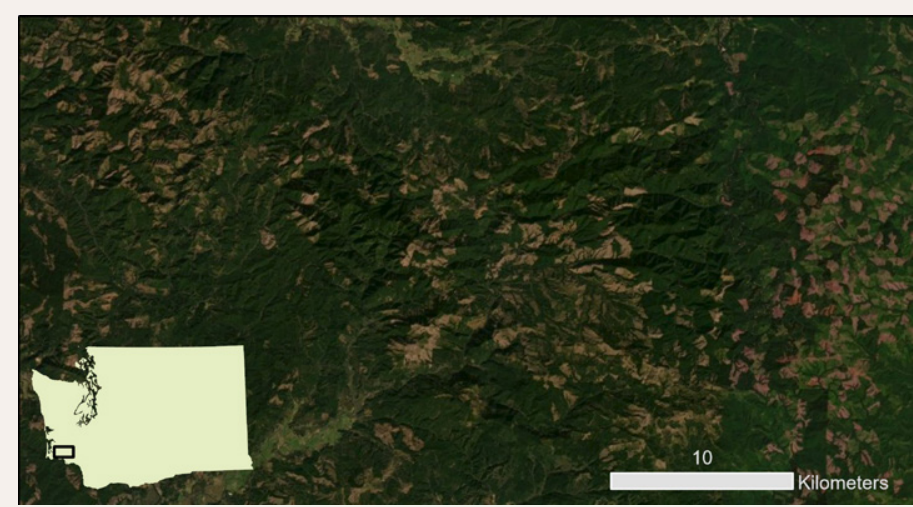

Figure 7. Commercial forest in various stages of growth in southern Pacific County. This image includes parts of areas 3 and 4 from Figure 6. Source: Esri Imagery basemap.

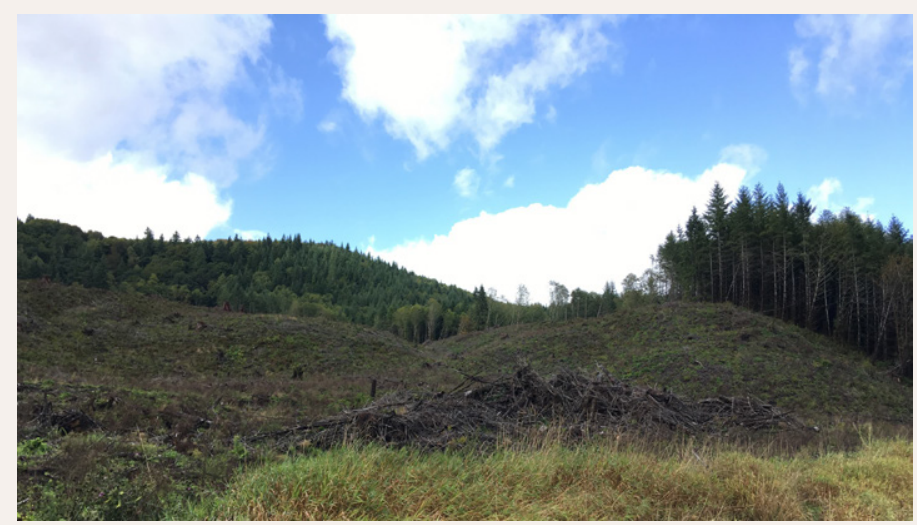

Figure 8. Clear-cut and other managed forest land in different stages of growth, Pacific County. Photo by author.
Rayonier, Hancock, Forest Investment Associates (FIA), and a handful of other private timber companies also manage lands in the empty spaces. The companies engage in strategic land swapping with each other to try to consolidate holdings and achieve the most profitable supply chains. Figure 9 shows the five largest landholders in Pacific County.

Only one major highway crosses this part of Washington. State Route 6 winds through the hills from Chehalis to Raymond, where a Weyerhaeuser mill takes in raw logs and outputs plastic-wrapped packages of lumber headed for The Home Depot and other domestic outlets. Still, this is a relatively small mill, and many of the ubiquitous logging trucks on the highway head west to Chehalis or Longview where they can fetch a higher price. Some of the trees wind up being shipped internationally. Piles of logs at the Port of Olympia await transport to Asian markets, where they will be milled according to metric standards.

On both sides of State Route 6, a vast labyrinth of narrow logging roads blankets the Willapa Hills. Traditionally,

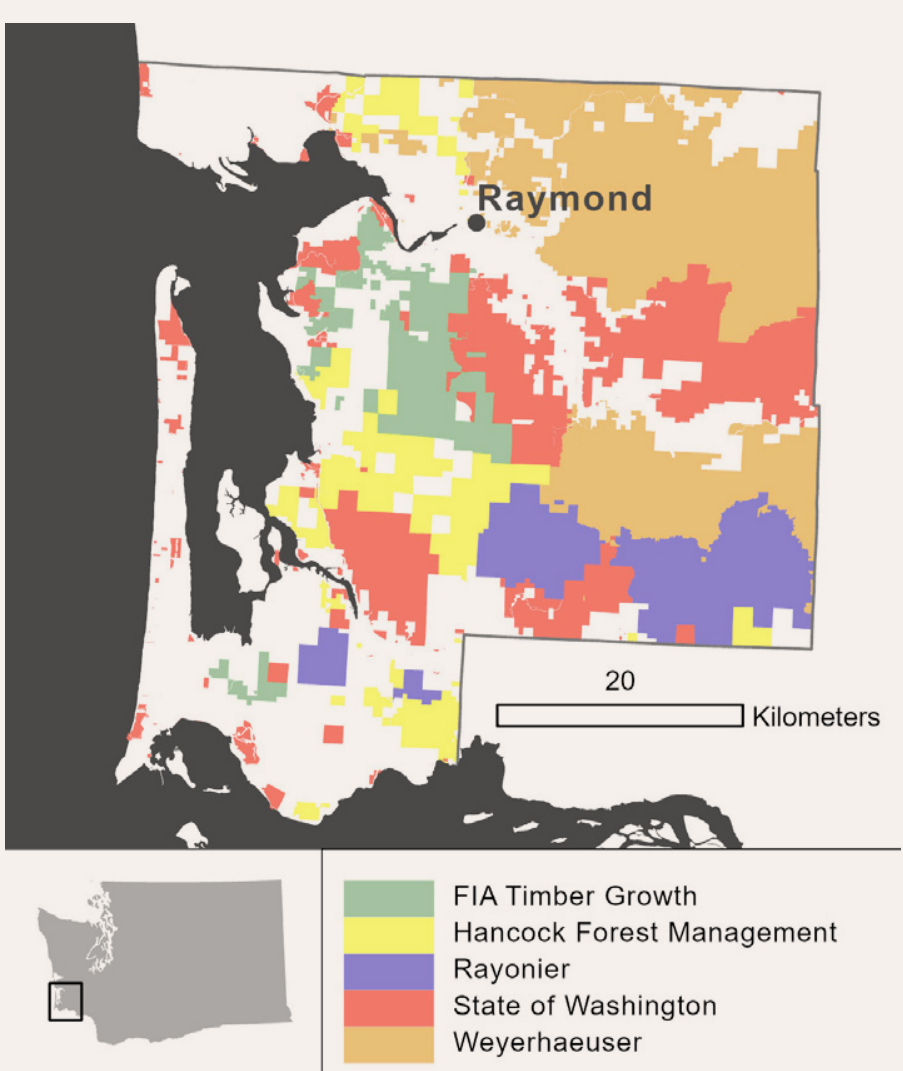

Figure 9. Land owners with the largest holdings in Pacific County, as determined from GIS tax parcels data obtained from the county in 2019. 
most private timber lands in this area were open for the public to roam, but in the past decade the companies have installed locked gates at their road entrances to deter dumping, poaching, and other destructive activities. Weyerhaeuser now operates a recreation permitting system that allows the company to claim some revenue from the use of the lands while keeping track of who enters. State roads are still open, although they are often narrow, unmarked, and difficult for ordinary passenger vehicles to navigate. Thus, much of the empty space on this part of the map is impenetrable by most of the local population, even though these people rely on the timber resources for economic support and public service funding.

In this part of Washington, clear-cuts are common sites. The denuded landscape can be a shock to visitors unaccustomed to the practices of commercial logging. It is more economically efficient for companies to harvest an entire stand, and the full sunlight allows the stand to regenerate more quickly, at an even pace. Such clear-cuts have recently been avoided in forests visible from the most urban parts of the state. Outside this view, in the empty areas of the map where rural economies and local budgets rely on logging, there is greater social license for clear-cutting and other rotational forest management practices.

\section{HIGH PLAIN BETWEEN THE OREGON BORDER AND THE YAKIMA VALLEY}

A second notable cluster of empty areas is found in South Central Washington, bounded by the Cascade Range to the west, the Horse Heaven Hills and Yakima Valley to the north, and the Columbia River to the east and south. Most of this land is situated on a sparsely-inhabited, high, and dry plain, punctuated only by the deeply gouged drainage systems of the Klickitat River, Rock Creek, and Alder Creek. These gulches hinder travel, and there is little reason for people to traverse them when Interstate Highways 82 and 84 offer quick east-west routes on either side.

The landscape in this area consists of large farms, ranches, and vineyards, as well as uncultivated rangeland. Coniferous forest appears in the higher elevations skirting the Cascades. Some of the farms are close enough to the Columbia to be fed by pumped water. Irrigation is often applied through center pivot systems that result in emerald circles on a satellite image. Potatoes, corn, onions, carrots, and other row crops flourish in this environment.
The largest of these irrigated farms in the study area (partially intersecting area 9 in Figure 6) is operated by AgriNorthwest, a for-profit subsidiary company of The Church of Jesus Christ of Latter-day Saints. The church's farmland holdings in Benton County alone total over 350 square kilometers, with additional land in Walla Walla County to the east. Latter-day Saint leadership has viewed agriculture as a safe and profitable investment for a portion of the church's finances, one that could be repurposed to bolster existing church welfare farming activity in times of extreme need (Deseret News 1991). Similar farms and ranches can be found throughout the United States, and in other countries such as Canada and Argentina.

To the northwest of this farm, the Horrigan family holds land and ranches totaling over 180 square kilometers in Benton County (straddling area 8 in Figure 6). Their wheat crops sit outside the irrigated region and depend on whatever moisture falls from the sky. In the early 1950s, then-owner Leo Horrigan was one of the first to experiment with hiring "rainmakers" who seeded clouds with silver-iodide particles in hopes of increasing raindrop production, an experiment that according to Frank Taylor (1954) was successful.

Further west, in Klickitat County, sprawling wind farms take advantage of air masses forced through the Columbia River Gorge (Sharp and Mass 2004; Figure 10). In 2005 the county designated an "energy overlay zone" to expedite the permitting process for wind power projects. This zone covers the entire eastern part of the county, which is otherwise empty space on the map, occupied by a few scattered farmers and ranchers. Wind developers flocked to the area, and within four years of the zone's creation, the county's taxable property base grew from $\$ 1.7$ billion to $\$ 3$ billion (Mulkern 2010). The revenues were enough to

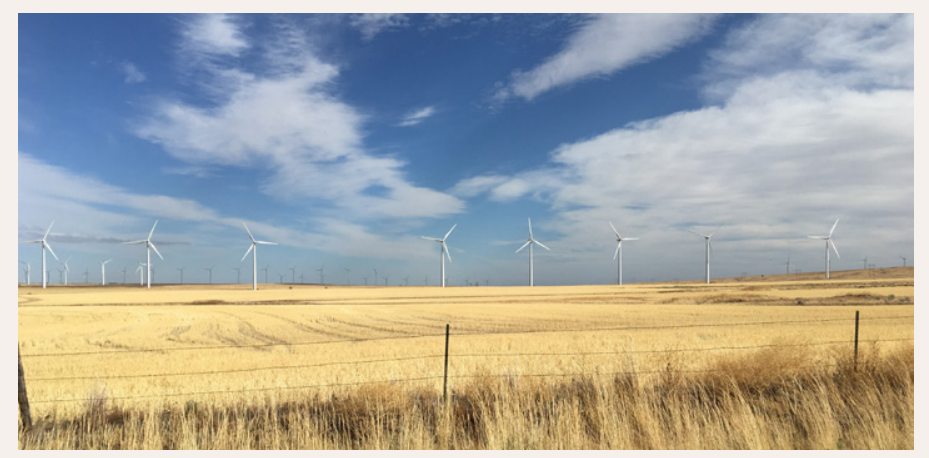

Figure 10. Wind power production in Klickitat County. Photo by author. 
finance a new high school in the only town in the county's eastern interior, Bickleton. At the time of this writing, the county's web site lists 14 permitted wind farms (klickitatcounty.org/273/Wind-Projects), which supply power to public and private utilities all over the Pacific Northwest. One of these intersects area 7 in Figure 6.

The region has also caught the eye of solar developers, and nearly seven square kilometers of mixed public and private land in Klickitat County are slated for the construction of half a million photovoltaic panels that will supply power to Puget Sound Energy (PSE). Financing stems from PSE's "Green Direct" plan, which allows its municipal and corporate customers (most of whom are located in suburban Seattle and Tacoma) to purchase 100\% of their power from local renewable sources (The Columbian 2019). ${ }^{5}$ The project, located fewer than $5 \mathrm{~km}$ west of area 8 in Figure 6, would be the largest solar power endeavor in Washington State.

In addition to supplying electricity to urban households, eastern Klickitat County also receives a substantial portion of their trash. Each day, multimodal shipping containers full of the Pacific Northwest's garbage arrive on rail cars at the small town of Roosevelt and are trucked up the hill to Republic Services' Roosevelt Regional Landfill, which takes refuse from as far away as Alaska. The ashes of burned trash from the city of Spokane are also brought to the landfill, where they are mined for metals before being laid to rest. Methane gas from beneath the landfill is harvested and converted into a natural gas product like that used for powering vehicles. The landfill itself sits in a natural bowl and is invisible to passers-by on paved county roads. Its underlying geology of low-permeability clay and basalt rock make it ideal for depositing trash, and Waste Management operates a facility of similar magnitude just across the river in Oregon. ${ }^{6}$

\section{DRYLANDS ON THE PERIPHERY OF THE COLUMBIA BASIN}

The third region abounding in cartographic empty spaces is arid farmland on the far reaches of the Columbia Basin in Douglas, Grant, Lincoln, and Adams Counties. The more populous, central part of the basin is irrigated through the Columbia Basin Project, a program run by

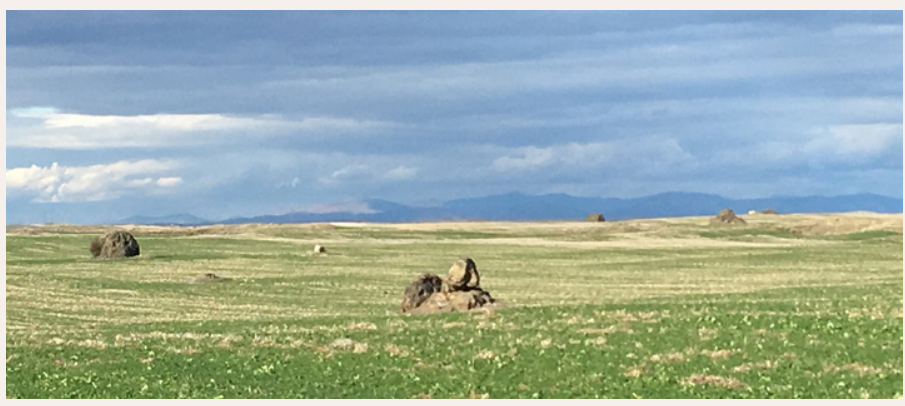

Figure 11. Cultivation around glacial erratics in Douglas County, Washington. Photo by author.

the United States Bureau of Reclamation to distribute water extracted at Grand Coulee Dam (usbr.gov/pn/project/brochures/columbiabasinproject.pdf). Beyond the extent of this project, the agricultural landscape changes to mostly dryland wheat farming, in which fields are frequently left fallow to absorb a year of the region's scant precipitation before replanting (Delevingne and Turner 2011, xiv). Most of this wheat is exported, with Asian countries such as the Philippines, Japan, and South Korea being top buyers from Washington State (Granillo 2019). Farmers must work around enormous "erratic" boulders left by ancient glaciers (Figure 11), and land too steep or rocky for cultivation is often given over to cattle grazing.

Infrastructural connections with the more urbanized western side of the state are still strong here, although perhaps difficult to see at first glance. Since 1992, wheat, hay, canola, and sunflower farms in rural Douglas County have received over 2 million tons of treated sewage sludge from around Washington State as "biosolid" fertilizer (King County and Boulder Park, Inc. 2019). The majority of this comes from the Seattle and Tacoma metro areas in tanker trucks that make their way over the Cascade Range. The program is operated as a public-private partnership between King County (which contains Seattle) and Boulder Park, Incorporated. Some of the participating farms fall within area 12 of Figure 6 , and others adjoin area 13 . Such applications of biosolids are generally accepted as an economical way to dispose of human waste while improving soil properties and providing an organic fertilizer option, although efforts are ongoing to understand the ways that long-term accumulation of pharmaceuticals and personal care products (PPCPs) in the biosolids might affect human food and drinking water supplies ( $\mathrm{Lu}, \mathrm{He}$, and Stofella 2012; Clarke and Cummins 2015; Healy et al. 2017).

5. For information on the Green Direct program, see pse.com/green-options/Renewable-Energy-Programs/green-direct.

6. Much of this information comes from my notes taken at the facility during their annual public open house in 2019. 
People have sought out the sunny reaches of the Columbia Basin periphery as a place to get away. A stark example is in area 15 of Figure 6 in the northern part of Grant County, just south of the town of Wilson Creek (imagery shown in Figure 12). Here, uncultivated rocky shrublands have been carved up into parcels and sold off as part of a development called Eagle Springs Ranch. "Private Road - No Trespassing” warnings adorn each road sign. According to local real estate agents, many owners have purchased these parcels in order to have their own slice of the wilderness where they can pursue rest or recreation in solitude. An advertisement for one such lot (now on the market for about 4 years) proclaims that the space is "perfect for horse riding, hunting, or just bring the RV and get away." A look through local tax records shows numerous owners from Seattle, Tacoma, and Southern California who have apparently been trying to do just that; however, the land is perhaps more remote than people bargained for and occupants must bring their own accommodations for electricity and water. Most lots have no vehicles or structures on them.

Next to this mostly absentee neighborhood lives the community of the Marlin Hutterian Brethren, surrounded by their farmlands. The Hutterites are a Christian sect that share roots with the Amish and Mennonites in the Anabaptist movement of the 1500s. Early Hutterite settlement in the Americas was largely confined to the Dakotas and the Prairie Provinces of Canada; however, in the 1950s and 60s, some Hutterites moved from Alberta to Washington State to take advantage of the longer growing season and fertile soils (Youmans 1995). Hutterite colonies regularly break off and migrate in this fashion to ensure that no one group grows unmanageably large. This pattern has produced four Hutterite colonies on the periphery of the Columbia Basin Project (Warden, Stahl, Marlin, and Schoonover), all established between 1972 and 1980 (Janzen and Stanton 2010, Appendix).

Hutterites live in colonies of typically 50-120 members, sharing material goods, favoring conservative dress, and attending daily religious services. They use modern farming technologies to provide the best yields possible for their communities, but prefer to avoid extensive contact with the rest of society. In some respects, they have sought out the empty spaces on the map to practice agriculture and live a life unsullied by outside interference. Ironically, the Warden Hutterian Brethren colony appears prominently on Google Maps at the scale studied here, due to what appears to be an algorithm filling empty spaces with places from the USGS Geographic Names Information System (GNIS) database. The colony is labeled with the same font size as the nearby city of Moses Lake, which has a population of over 20,000 (Figure 13). 
What CREATEd these empty areas on the Washington State maps? In some cases, physical geography impeded human settlement in the area by making the spaces difficult to reach or traverse; yet, the areas also escaped any kind of protected status that would cause them to appear on a map. Such is the case with the Alder Creek watershed previously discussed (area 8 in Figure 6), or a feature marked on topographic maps as simply "The Plateau" nestled between the Cascade Range and the Klickitat Canyon (area 6 in Figure 6). Eastern Washington's glaciated landscape of deep coulees and river gorges creates a lot of "dead ends" with relatively little human settlement. Klimm (1954) noted a similar effect in the peninsular southern part of New Jersey.

Empty spaces also resulted from cartographers who chose to not to collect or include information about certain kinds of human activities and land uses. For example, it is not customary in these maps to describe private land ownership or development, even when tracts cover hundreds of square miles. Such practices could reflect cultural respect toward privacy, an unwillingness to be held liable for depictions of cadastral boundaries, or a hesitance to appear overly favorable or hostile toward any particular owner or activity.

The identified empty spaces in the Washington State maps play a role in shaping the landscape through public discourse, imagination, and activities. Since many of these spaces are used for energy production, waste disposal, and other NIMBY activities that sustain urban life, the blank spots on the map help perpetuate the shortsighted ideas that sewage and trash just "go away," and that electricity magically originates in the wall socket. The omission of large-scale energy and industrial projects on the map plays a role in keeping these activities outside of the public mind and scrutiny, while also discouraging personal visits to or explorations of the landscapes.

When it comes to protected areas, the empty spaces on the map may play a role in perpetuating myths of "wild nature," or the idea that broad swaths of the rural landscape remain unaffected by human activity. And although the frequent omission of locally protected landscapes such as state wildlife areas may keep people away from these places and thereby reduce human impact, the cartographic silence may become a liability if the protection is able to be rescinded or sold off with less public awareness.

\section{GEOGRAPHIC CONNECTIONS}

Despite their sparse populations, empty spaces on the map should not be considered isolated or excluded from regional or global economic processes. Everyday urban activities such as flipping on a light switch, throwing something in the trash, flushing the toilet, or cooking dinner are dependent on activities in these places. At the same time, town and county governments near the empty spaces have developed some fiscal reliance on urban consumption.

Driving to Washington's empty spaces is a good way to see trucks. These roaring behemoths transport trees, vegetables, garbage, and treated sewage all around the Northwest, passing every couple of minutes on some roads I traveled. Some of the food and timber produced in Washington's empty spaces is taken to ports and shipped overseas to international markets. Events thousands of miles away can and do affect daily life for residents of the empty spaces who depend on these markets.

Mitchell (2008) observed that landscapes are deeply functional in the capitalist society. This is true of the empty spaces on the map, many of which have been acquired by big industries who can use them to achieve economies of scale and conduct activities away from the public view. Examples mentioned in this study are Weyerhaeuser, Rayonier, AgriNorthwest, Republic Services, Boulder Park, and the myriad energy companies operating wind (and soon solar) projects.

Areas not swallowed up by industry have been sought out by people desiring a few acres of their own to live or play in solitude. Intruders are not always welcome. Even while driving on a public road, my effort to visit one of the empty map spaces was interrupted by a man suspicious of what I was doing near his property (turns out that theft had been a problem). The smaller individual parcels intermingle with the large projects to create an intriguing patchwork of individuals and corporations that want to remain unbothered. 


\section{POTENTIAL INTERVENTIONS}

These many examples prove Harley right: even in the map's silences, there are consequential things happening. How, then, should cartographers make decisions about what to show in these spaces? Communicating some element of land use or land cover is one way to begin. The Esri Topographic basemap does this, using green tints to depict areas covered by forest and irrigated agriculture. The main map on OpenStreetMap.org also shows various land use categories, although many remain to be filled in by users. In early 2020, about the time this paper was going to press, Google Maps added green tints on thickly forested areas. This effectively "filled in" some of the blank areas in southwestern Washington, while revealing rotational patterns of forest management.

This study has demonstrated that protected areas at the state and municipal levels are sometimes overlooked in maps. Giving more prominence to these areas would increase map readers' awareness of their connections with the Earth's resources and how those are conserved, used, or exploited. National forests and parks were prominently symbolized on the studied maps, but common citizens might be able to exercise a more direct influence on the management and use of local parks, refuges, and reserves if these places become more widely known and recognized.

Cartographers working on algorithmically-generated maps can look to expand their databases of points of interest beyond pizza restaurants and public buildings to include some of the vital industry and infrastructure (both public and private) supporting day-to-day life, such as major farms, landfills, energy projects, and commercial forests. Crowdsourcing provides opportunities to infuse local context and variety into the set of map features. Web maps could also invite users to interactively explore the landscape, to click any map area and learn more. Google Maps's "What's here?" option allows the user to retrieve an address and street-level imagery thumbnail (where such images exist). Such options might be expanded by ancillary text, user-contributed photography, alternative map depictions (even countercartographies), and so forth.

\section{SUGGESTIONS FOR FURTHER RESEARCH}

This study has only examined a single scale and type of map. Since web maps change their representation as users zoom in and out, research is needed about which areas persist as empty at each scale. Such an inquiry from the top scale down might result in empty "volumes" that could then be further interrogated for connections with land ownership and use, following the patterns presented in this study.

Finally, it would be useful to understand how map readers interact with and interpret empty spaces. Danyel Fisher's (2007) "Hotmap" of Microsoft's online map tile access showed that user attention focuses on urban areas, coastlines, and highway networks. People interact most with the lands they know and traverse. Outside of those areas, does the lack of features at one scale prevent users from zooming in further to discover more, or does the emptiness encourage them to drill in and explore? These are related to larger questions about how web maps and their empty spaces are associated with geographic literacy and understandings of place. This is an important topic for a generation that has grown up with online maps, where companies like Google, Microsoft, and Apple define the empty spaces and shape human perceptions of the world.

\section{ACKNOWLEDGEMENTS}

I THAnk Sarah Hibdon, David Cordner, and Allen Quinn for their help with data processing and field work. Todd Bates at Grays Harbor College provided much information on forestry practices. I also appreciate the many workers in local industries who took time to hear about this project and share their thoughts. The editors and peer reviewers for Cartographic Perspectives offered many suggestions that improved this paper.

This work was supported by a faculty early career grant from the Central Washington University College of the Sciences. 
Brunn, Stanley D., and Matthew W. Wilson. 2013. “Cape Town's Million plus Black Township of Khayelitsha: Terrae Incognitae and the Geographies and Cartographies of Silence." Habitat International 39: 284-294. https://doi.org/10.1016/j. habitatint.2012.10.017.

Bryan, Joe, and Denis Wood. 2015. Weaponizing Maps. New York: Guilford Press.

Clarke, Rachel, and Edna Cummins. 2015. "Evaluation of 'Classic' and Emerging Contaminants Resulting from the Application of Biosolids to Agricultural Lands: A Review." Human and Ecological Risk Assessment 21 (2): 492-513. https://doi.org/10.1080/10 807039.2014.930295.

Cosgrove, Denis. 1989. "Geography Is Everywhere: Culture and Symbolism in Human Landscapes." In Horizons in Human Geography, edited by Derek Gregory and Rex Walford, 118-135. London: Macmillan Education UK. https://doi. org/10.1007/978-1-349-19839-9_7.

Crampton, Jeremy W. 2001. "Maps as Social Constructions: Power, Communication and Visualization." Progress in Human Geography 25 (2): 235-252. https://doi. org/10.1191/030913201678580494.

Dalton, Craig M., and Jim Thatcher. 2019. "Seeing by the Starbucks: The Social Context of Mobile Maps and Users' Geographic Knowledges." Cartographic Perspectives 92: 24-42. https://doi.org/10.14714/ CP92.1447.

Delano-Smith, Catherine. 2004. "Smoothed Lines and Empty Spaces: The Changing Face of the Exegetical Map before 1600.” In Combler Les Blancs de La Carte, edited by Isabelle Laboulais, 17-34. Strasbourg, France: Presses Universitaires de Strasbourg.

Dent, Borden D. 1999. Cartography: Thematic Map Design. New York: WCB McGraw Hill.

Delevingne, Lionel, and Steve Turner. Drylands, a Rural American Saga. Lincoln, Nebraska: University of Nebraska Press, 2011.
Deseret News. 1991. "LDS Church Real-Estate Holdings Include Farms, Ranches, Buildings." Deseret Nerws, July 2, 1991. https://www.deseret. com/1991/7/2/18928879/1ds-church-real-estateholdings-include-farms-ranches-buildings.

Field, Kenneth. 2018. Cartography. Redlands, California: Esri Press.

Fisher, Danyel. 2007. "Hotmap: Looking at Geographic Attention." IEEE Transactions on Visualization and Computer Graphics 13 (6): 1184-1191. https://doi. org/10.1109/TVCG.2007.70561.

Granillo, Aaron. 2019. "US-China Trade War Expected to Hit Washington Farmers Hard.” MyNorthwest.Com, August 7, 2019. https://mynorthwest.com/1472711/us-china-trade-war-expected-to-hit-washingtonfarmers-hard/?.

Hagen, Erica. 2011. "Mapping Change: Community Information Empowerment in Kibera (Innovations Case Narrative: Map Kibera)." Innovations: Technology, Governance, Globalization 6 (1): 69-94. https://doi. org/10.1162/INOV_a_00059.

Harley, J. B. 1988. "Silences and Secrecy: The Hidden Agenda of Cartography in Early Modern Europe." Imago Mundi 40: 57-76. http://doi. org/10.1080/03085698808592639.

1990. "Introduction: Text and Contexts in the Interpretation of Early Maps." In From Sea Charts to Satellite Images: Interpreting North American History Through Maps, edited by David Buisseret, 3-15. Chicago: University of Chicago Press.

- 2001. The New Nature of Maps: Essays in the History of Cartography. Baltimore: The Johns Hopkins University Press.

Healy, Mark, Owen Fenton, Edna Cummins, Rachel Clarke, Dara Peyton, Ger Fleming, David Wall, Liam Morrison, and Martin Cormican. 2017. Health and Water Quality Impacts Arising from Land Spreading of Biosolids. Wexford, Ireland: Environmental Protection Agency (Ireland). https://www.epa.ie/pubs/reports/ research/land/research200.html. 
Janzen, Rod, and Max Stanton. 2010. The Hutterites in North America. Baltimore: The Johns Hopkins University Press.

Julyan, Robert. 2000. "Protecting the Endangered Blank Spots on Maps: The Wilderness Names Policy of the United States Board on Geographic Names." Names 48, (3-4): 217-226. https://doi.org/10.1179/ nam.2000.48.3-4.217.

Kimerling, A. Jon, Aileen R. Buckley, Phillip C. Muehrcke, and Juliana O. Muehrcke. 2012. Map Use: Reading, Analysis, Interpretation, Seventh Edition. Redlands, California: Esri Press Academic.

King County, and Boulder Park, Inc. 2019. Boulder Park Project: 2018 Annual Report. https://www.kingcounty. gov/ /media/services/environment/wastewater/ resource-recovery/docs/biosolids/2018_LoopBoulder-Park-Report.ashx?la=en.

Klimm, Lester E. 1954. "The Empty Areas of the Northeastern United States." Geographical Review 44 (3): 325-345. https://doi.org/10.2307/212060.

Krygier, John, and Denis Wood. 2016. Making Maps: A Visual Guide to Map Design for GIS, Third Edition. New York: Guilford Press.

Lewis, Pierce. 1979. "Axioms for Reading the Landscape." In The Interpretation of Ordinary Landscapes, edited by Donald Meinig, 11-32. Oxford: Oxford University Press.

Lu, Qin, Zhenli L. He, and Peter J. Stoffella. 2012. "Land Application of Biosolids in the USA: A Review." Applied and Environmental Soil Science 2012: Article 201462. https://doi.org/10.1155/2012/201462.

McConchie, Alan. 2019. "Cartography and Community in OpenStreetMap: Getting Native Reservations on the Map." NACIS 2019 Annual Meeting. Tacoma, Washington, United States. https://youtu.be/ fTJU3xaYQxE.
Mitchell, Don. 1994. "Landscape and Surplus Value: The Making of the Ordinary in Brentwood, CA." Environment and Planning D: Society and Space 12 (1): 7-30. https://doi.org/10.1068/d120007.

2008. "New Axioms for Reading the Landscape: Paying Attention to Political Economy and Social Justice." In Political Economies of Landscape Change: Places of Integrative Power, edited by James L. Wescoat and Douglas M. Johnston, 29-50. Dordrecht: Springer Netherlands. https://doi. org/10.1007/978-1-4020-5849-3_2.

Mulkern, Anne C. 2010. "Wind Is the New Cash Crop in Rural Wash. Town." New York Times, October 18, 2010. https://archive.nytimes.com/www.nytimes. com/gwire/2010/10/18/18greenwire-wind-isthe-new-cash-crop-in-rural-wash-town-3529. html?emc=rss\&partner=rss.

Novaes, André Reyes. 2014. "Favelas and the Divided City: Mapping Silences and Calculations in Rio de Janeiro's Journalistic Cartography." Social \& Cultural Geography 15 (2): 201-225. https://doi.org/10.1080/14 649365.2013.872285.

O'Sullivan, David, and David Unwin. 2003. Geographic Information Analysis, First Edition. Hoboken, New Jersey: John Wiley \& Sons.

Paglen, Trevor. 2009. Blank Spots on the Map: The Dark Geography of the Pentagon's Secret World. New York: Dutton.

Perkins, Chris, and Martin Dodge. 2009. "Satellite Imagery and the Spectacle of Secret Spaces." Geoforum 40 (4): 546-560. https://doi.org/10.1016/j. geoforum.2009.04.012.

Quinn, Sterling, and Lakshman Yapa. 2016. "OpenStreetMap and Food Security: A Case Study in the City of Philadelphia." The Professional Geographer 68 (2): 271-280. https://doi.org/10.1080/00330124.20 15.1065547 .

Robinson, Arthur H., Joel L. Morrison, Phillip C. Muehrcke, A. Jon Kimerling, and Stephen C. Guptill. 1995. Elements of Cartography, Sixth Edition. New York: John Wiley \& Sons. 
Sauer, Carl Ortwin. 1925. The Morphology of Landscape. Berkeley, California: University of California Press.

Sharp, Justin, and Clifford F. Mass. 2004. "Columbia Gorge Gap Winds: Their Climatological Influence and Synoptic Evolution." Weather and Forecasting 19 (6): 970-992. https://doi.org/10.1175/826.1.

Stevenson, Seth. 2012. "The Greatest Paper Map of the United States You'll Ever See.” Slate, January 2, 2012. https://slate.com/culture/2012/01/the-best-americanwall-map-david-imus-the-essential-geography-ofthe-united-states-of-america.html.

Taylor, Frank J. 1954. “They Make Rain.” Prairie Schooner 28 (2): 157-161.

The Columbian. 2019. "State's Largest Solar Project Planned in Klickitat County." The Columbian, March 15, 2019. https://www.columbian.com/news/2019/ mar/15/states-largest-solar-project-planned-inklickitat-county/.
Tuan, Yi-Fu. 1979. "Space and Place: Humanistic Perspective." In Philosophy in Geography, edited by Stephen Gale and Gunnar Olsson, 387-427. Dordrecht: Springer Netherlands. https://doi. org/10.1007/978-94-009-9394-5_19.

Wilmott, Clancy. "'Mapping-with': The Politics of (Counter-)Classification in OpenStreetMap." Cartographic Perspectives 92: 43-57. https://doi. org/10.14714/CP92.1451.

Wright, John K. 1947. "Terrae Incognitae: The Place of the Imagination in Geography." Annals of the Association of American Geographers 37 (1): 1-15. https:// doi.org/10.2307/2561211.

Youmans, Vance Joseph. 1995. The Plough and the Pen: Paul S. Gross and the Establishment of the Spokane Hutterian Brethren. Boone, North Carolina: Parkway Publishers. 